\title{
ANALISIS TINGKAT PELAYANAN DAN KENYAMANAN JALUR PEDESTRIAN DI JALAN GAJAH MADA, DIPONEGORO DAN PAHLAWAN BERDASARKAN PERSEPSI PENGGUNA
}

\author{
Lailatul Kiftiyah ${ }^{1)}$ dan Jelita Citrawati Jihan ${ }^{2)}$ \\ ${ }^{1,2)}$ Perencanaan Wilayah dan Kota, Fakultas Teknik Sipil dan Perencanaan \\ Universitas PGRI Adi Buana Surabaya \\ Email: 1kiftiyah80@gmail.com
}

\begin{abstract}
Abstrak
Jalan Gajah Mada, Diponegoro dan Pahlawan merupakan kawasan yang memiliki tingkat keramaian yang tinggi karena adanya pusat kegiatan perdagangan, jasa dan perkantoran di Sidoarjo. Permasalah yang terjadi di jalan tersebut adalah banyaknya parkir liar dan rusaknya jalur pedestrian. Penelitian ini bertujuan untuk mengetahui kondisi fisik jalur pedestrian, mengetahui tingkat pelayanan serta tingkat kenyamanan berdasarkan persepsi pengguna. Metode penelitian menggunakan deskriptif kualitatif dan kuantitatif dengan teknik analisis LOS (Level Of Service) dan AHP (Analysis Hierarcy Process). Metode pengumpulan data dilakukan dengan cara survey lapangan, sebar kuisioner dan dokumentasi. Hasil dari penelitian ini ialah kondisi fisik jalur pedestrian di Jalan Gajah Mada, Diponegoro dan Pahlawan telah sesuai dengan pedoman. Jika ditinjau dari tingkat pelayanan Jalan Gajah Mada tergolong tingkat B, sedangkan Jalan Diponegoro dan Pahlawan tergolong tingkat pelayanan A. Para pengguna merasa aman dan nyaman saat berjalan di jalur pedestrian Jalan Gajah Mada, Diponegoro dan Pahlawan. Arahan pengembangan untuk jalur pedestrian berdasarkan hasil AHP yaitu alternatif 1 ( satu) relokasi area parkir agar tidak menggunakan jalur pedestrian 40,8\%, alternatif 2 (dua) Perbaikan kondisi fisik jalur pedestrian 42\% dan alternatif 3 (tiga) Peningkatan keterseediaan elemen pendukung jalur pedestrian 17,2\%.
\end{abstract}

Kata kunci : Kenyamanan, Kondisi Jalur Pejalan Kaki, Tingkat Layanan 


\section{REFERENSI/DAFTAR PUSTAKA}

Peraturan Menteri Pekerjaan Umum Nomor: 03/PRT/M/2014. (2014) Tentang Pedoman Perencanaan, Penyediaan, Dan Pemanfaatan Prasarana Dan Sarana Jaringan Pejalan Kaki Di Kawasan Perkotaan. Jakarta (ID): Departemen Pekerjaan Umum.

Wismonowati, Dewi. (2012)._Kajian Tingkat Kenyamanan Fisik Ruang Dalam Berdasarkan Persepsi Pengguna. Semarang: Universitas Negeri Semarang

Dharmawan, Doddy. (2004). Mengamati Peran Pedestrian dalam Kehidupan Sosial Ekonomi Masyarakat Studi Kasus Sudirman-Thamrin Jakarta. Skripsi Tugas Akhir Jurusan Arsitektur Universitas Muhammadiyah Jakarta. Jakarta (ID): Universitas Muhammadiyah Jakarta.

Harsono, S. (2016). Persepsi Pejalan Kaki Terhadap Kenyamanan Jalur Pejalan Kaki Dipusat Kota. Tesis. Medan (ID): Universitas Sumatera Utara.

Inayati, M., Jihan, J. C., \& Abhirama, T. (2015). Persepsi dan preferensi pengunjung untuk arahan penataan taman abhirama. 1-14.

Iswanto, Danoe, (2006). Pengaruh Elemen Elemen Pelengkap Jalur Pedestrian Terhadap Kenyamanan Pejalan Kaki Studi Kasus Penggal Jalan Pandanaran Dimulai dari Jalan Randusari Hingga Kawasan Tugu Muda. Semarang (ID): Universitas Negeri Diponegoro.

Kusmeilan, E., Prasetyanto. D., \& Maulana, A. (2018). Tingkat Pelayanan Pejalan Kaki pada Skywalk Jalan Cihampelas Kota Bandung. Bandung (ID): Institut Teknologi Nasional. 